\title{
A note on 20-species lists
}

\author{
BENT OTTO POULSEN, NIELS KRABBE, AMY FRØLANDER, MARCELO \\ B. HINOJOSA and CARMEN O. QUIROGA
}

Since our paper on the efficiency and biases of 20-species lists (Poulsen et al. 1997) went to press we have recognized a further two biases in the method, after discussions with C. Rahbek. We remarked in our paper that the abundance curves were behaving raiher strangely and that "the importance of these phenomena needs to be investigated in more detail". The behaviour may be due to the method setting constraints on the highest possible frequency, namely the number of times a species occurs in 20-species lists. This could affect the calculation of the expected abundances and hence the $\alpha$-index. Another bias must be the indirect way of determining the relative abundances, ignoring the true number of individuals. A species with many individuals will be given the same relative abundance as a species with very few individuals if both species occur in the same number of 20-species lists. We do not know the importance of these constraints but recommend that the method is not used until the results of a current computer modelling study examining its efficiency (S. Herzog and M. Kessler pers. comm.) are known.

\section{Reference}

Poulsen, B. O., Krabbe, N., Frølander, A., Hinojosa, M. B. and Quiroga, C. O. (1997) A rapid assessment of Bolivian and Ecuadorian montane avifaunas using 20-species lists: efficiency biases and data gathered. Bird. Conserv. Internatn. 7: 53-67.

BENT OTTO POULSEN, NIELS KRABBE, AMY FRØLANDER, MARCELO B. HINOJOSA and CARMEN O. QUIROGA

Zoological Museum, University of Copenhagen, Universitetsparken 15, 2100 Copenhagen $O$, Denmark. 